\title{
Effect of Different substrate Disinfection Methods on the Production of Pleurotus ostreatus
}

\author{
Funda ATİLA (Corresponding author) \\ Department of Horticulture, Ahi Evran University \\ 40200, Kırşehir, TURKEY \\ Tel: + 90-386-280 4814 E-mail: fundacavuslar@hotmail.com
}

\begin{abstract}
Received: October 8, 2016 Accepted: October 21, 2016 Published: October 31, 2016
doi:10.5296/jas.v4i4.10051ＵRL: http://dx.doi.org/10.5296/jas.v4i4.10051
\end{abstract}

\begin{abstract}
The aim of this paper is to estimate which of disinfection method is more effective in case of higher yield and fewer cost in cultivation of Pleurotus ostreatus in rural areas. For this purpose, four different treatments; scalping in hot water $\left(60,80\right.$ and $\left.100^{\circ} \mathrm{C}\right)$, and chemical disinfection ( $1 \%$ formaldehyde) were compared with sterilization by autoclave. It has been noticed that method of disinfection affects mycelium growing duration(day), yield $(\mathrm{g} / \mathrm{kg})$, biological efficiency $(\mathrm{BE} \%)$, avarage weight of fruitbody $(\mathrm{g})$, diameter of pileus $(\mathrm{cm})$, stipe lenght $(\mathrm{cm})$ and width $(\mathrm{cm})$. P. ostreatus took significantly much time to colonise the substrate (19.9 days) disinfected by chemical disinfection compared with others. Chemical disinfection $(271.28 \mathrm{~g} / \mathrm{kg}$ and $91.96 \%)$ and scalding hot water at $80^{\circ} \mathrm{C}(263.42 \mathrm{~g} / \mathrm{kg}$ and $90.83 \%$ ) had highest productivity in terms of yield and BE, respectively, while scalding hot water at $60^{\circ} \mathrm{C}(136.08 \mathrm{~g} / \mathrm{kg}$ and $46.92 \%)$ had least productivity. The largest diameter of fruitbody was obtained by scalding in hot water at $80^{\circ} \mathrm{C}$, while the longest stipes were harvested in disinfected substrate by chemicals. In conclusion, cheaper and more easily applecable scalping in hot water $80^{\circ} \mathrm{C}$ and chemical disinfection may be use for the disinfection of growing substrates instead of sterilization with autoclave in rural areas.
\end{abstract}

Keywords: mushroom growing substrate, disinfection methods, autoclaved, scalding, chemical disinfection, Pleurotus ostreatus

\section{Introduction}

Mushroom cultivation has long been a bioconversion process and a useful approach to treating solid agricultural and industrial wastes in both developed and developing countries (Levanon, Danai \& Masaphy, 1993; Chang 2006).

Pleurotus ostretaus (oyster mushrooms) are the second largest commercially cultivated mushroom in the world (Royse, 2013) because of its flavour, good taste, high nutritional and 
medicinal properties (Ganeshan, Tewari \& Bhargova,1989; Wang, Sakoda \& Suzuki, 2001; S.Yıldı, Ü.C.Yıldız, Gezer \& Temiz, 2002; Silva, Dias, Siqueira, Schwan \& 2007).

Masarirambi, Mamba \& Earnshaw (2011) suggested that mushroom cultivation is an alternative way of enhancing income level in developing countries due to its possibility of low cost of production, high profit and quick returns. Ability of $P$. ostretaus is high to adapt varied agro-climatic conditions (Jandaik \& Goyal, 1995) and different agricultural wastes (Nwokoye, Kuforiji \& Oni, 2010). P. ostretaus was introduced in the 1970s to Turkey and cultivation of this mushroom has significantly increased since five years (Eren \& Pekşen, 2016). In Turkey, small scale growers generally buy growing substrates from several compost companies. For this reason, cost of production is increased greatly. On the other hand, some growing substrates sold by malicious people may cause major losses on the production because of wrong substrat formula, unsufficient disinfection, etc. If growers prepare their own growing substrates, this may be a solution to solve the problem.

Oyster mushroom can be grown on various substrates due to its strong enzymatic features. Different agricultural wastes used to prepare the substrates in each region depend on locally available agricultural (Cohen, Persky \& Hadar, 2002). Wheat straw, sawdust and other agricultural by-products resulting after processing of waste paper, hazelnut and tilia (Y1ldiz et al.,2002), maize, corn, rice, elephant grass (Obodai, Cleland-Okine \& Vowotor, 2003), sugarcane (Membrillo, Sánchez, Meneses, Favela \& Loera, 2011), coffee (Gume, Diriba Mulata \& Abate, 2013) have been examined as alternative substrates for its cultivation.

Selectivity is important to determinate the quality of the growing substrate. Growing substrate must present the best conditions for efficient and fast colonization by the mushroom mycelium. Mushroom growth in the substrate, yield and quality can be limited by competitor bacteria and undesirable fungi. So growing substrates of $P$. ostreatus require some pretreatment in order to eleminate other microorganisms and enhancing mushroom mycelium growth. One of the most important step in the preparation of mushroom growing substrate is disifection which is referred to as pasteurization or sterilization.

The most commonly used by growing substrates producers in Turkey by steam pasteurization. Although there are a lot of alternative procedures for substrate preparation, most of the papers published by the scientific community report a preference for substrate previously sterilized in an autoclave (Bonatti, Karnopp, Soares \& Furlan, 2004; Shah, Ashraf \& Ishtiaq, 2004.; Marino , Abreu, Mesquita \& Ribeiro, 2008). Limited investment in appropriate infrastructures is a limiting factor for small producers (Dias, 2010). Morever, these methods are not an easy job for small scale growers in the rural areas.

Different disinfection methods can be used for cultivation of oyster mushroom production and its yield improvement (Khan, 2009). Jaramillo \& Albertó, (2013) were reported also that various treatments such as steam sterilization, steam pasteurization, hot water immersion and chemical treatment are used for the preparation of substrate for mushroom cultivation to eliminate competitive fungi .

Scalding of the substrate does not demand a large investment and it is cheaper because it requires fewer energy outlay. On the other hand, chemical sterilization is used for disinfection 
of casing materials in mushroom production.

The main objective of present research is finding out a cheaper and more easily applecable for the disinfection of growing substrates instead of sterilization with autoclave in rural areas. For this purpose, easily applicable methods for the disinfection (scalding in hot water at different temperature and chemical disinfection) was compared with using autoclave sterilization on oyster mushroom growth, yield and features of fruitbodies.

\section{Materials and Methods}

\subsection{Materials}

Agricultural wastes were obtained from local markets (Kırşehir, Turkey). Pure cultures of Pleurotus ostretus (HK-35 strain) was provided from a mushroom spawn company. The cultures were maintained in a potato dextrose agar (PDA) medium and stored in a refrigerator at $4{ }^{\circ} \mathrm{C}$. This study was conducted at the Mushroom Production Unit of Ahi Evran University's Faculty of Agriculture in Kırşehir, Turkey.

\subsection{Spawn Production}

Spawn was prepared on wheat grains as describe by Pieckenstain, Mercuri \& Albertó (1999). Briefly, wheat grains was boiled and then glass bottles filled with boiled wheat grains and $1 \% \mathrm{w} / \mathrm{w} \mathrm{CaCO}_{3}$ were sterilized for $1.5 \mathrm{~h}$ at $121{ }^{\circ} \mathrm{C}$, cooled and inoculated with an agar plug (1 cm diam.) cut from the advancing margin of a 5-d-old colony grown on PDA. Bottles were incubated in the dark, at $25^{\circ} \mathrm{C}$ until the completion of mycelial growth.

\subsection{Preparation of Cultivation Substrates}

Mixture of poplar sawdust (40\%) and wheat straw (40\%) was used as a base medium, and wheat bran was added to this mixture at ratios of $20 \%$ to prepare the growing substrates. Substrate was thoroughly mixed and then disenfected using the following methods viz., steam sterilization in autoclave at $121^{\circ} \mathrm{C}$ for $90 \mathrm{~min}$, scalding in hot water at $60^{\circ} \mathrm{C}, 80{ }^{\circ} \mathrm{C}$ and $100{ }^{\circ} \mathrm{C}$ for $1 \mathrm{~h}$ and chemical disinfection by formaldehyde.

In chemical sterilization, $250 \mathrm{ml}$ formalin $(40 \%)$ was added to $10 \mathrm{~L}$ water. Then the substrate was soaked in chemical solution overnight. After overnight soaking the substrate was aerated for few minutes and then filled to polythene bags.

After disenfection, $1 \mathrm{~kg}$ (wet weight) of each experimental group was packed into a plastic bag of $25 \times 45 \mathrm{~cm}$ and inoculated in a laminar flow chamber using 3\% grain spawn (on a w/w wet weight basis). The bags were plugged with a cotton plug.

\subsection{Experimental design and Mushroom Cultivation}

The experiment was conducted in a randomized plot design. Ten replicates were performed for each desenfection method.

Inoculated bags were incubated at $25 \pm 2{ }^{\circ} \mathrm{C}$ with $80 \%$ relative humidity in the presence of light to be colonized by the mycelium. After full colonization, bags were transferred to a cropping room at $17 \pm 2{ }^{\circ} \mathrm{C}$ with a humidity of $80-90 \%$ in order to induce fructification. The cotton plugs were removed and the tops of the bags were folded down. Cool white fluorescent bulbs provided $8 \mathrm{~h}$ of light daily. Sufficient air changes were maintained to 


\section{Macrothink}

Journal of Agricultural Studies

ISSN 2166-0379

2016, Vol. 4, No. 4

prevent high $\mathrm{CO}_{2}$ concentration. Total mushroom yield ( $\mathrm{g} \mathrm{kg}-1$ substrate) was obtained from three flushes in a harvest period. Mushrooms were harvested as soon as the fruiting bodies developed and attained their full size above the substrate with sharp knife from each treatment bag. The following data were recorded; days taken for the completion of substrate colonisation, number of days to pinhead formation and first fruiting. Morever weight of basidiocarps $(\mathrm{g})$, mushroom pileus diameter $(\mathrm{cm})$ and stipe diameter $(\mathrm{cm})$, stipe length $(\mathrm{cm})$, total mushroom yield $(\mathrm{g})$ and bio- efficiency\% (BE\%) were also measured among the treatments.

The biological efficiency percentage (BE\%) was calculated as follows: ([weight of fresh mushrooms harvested/substrate drymatter content] $\times 100$ ) (Royse, 1985). 2.5. Statistical Analysis

The data obtained from the experiment were subjected to variance and means analysis, and the statistical significance was compared employing Duncan'smultiple range test, using the SPSS 16.0 for Windows statistical computer program at a significance level of 5\%.

\section{Results and Discussions}

3.1. Number of days taken for full colonisation of substrate, pinheads and fruiting bodies formation

Significant differences were found among the different disinfection methods regarding number of days taken for full colonisation of substrate, pinheads and fruiting bodies formation of $P$. ostreatus (HK-35) as shown in Table 1.

Table 1. Effect of different growing media on spawn running time, pinheads formation and fruiting bodies 
formation of Pleurotus ostreatus (HK-35)

\begin{tabular}{lccc}
\hline Treatment & $\begin{array}{c}\text { Days for completion } \\
\text { of spawn running }\end{array}$ & $\begin{array}{c}\text { Days for pinhead } \\
\text { formation }^{1}\end{array}$ & $\begin{array}{c}\text { Days for fruitbodies } \\
\text { formation }^{1}\end{array}$ \\
\hline Autoclave & $17,0^{\mathrm{a} * *}$ & $24,1^{\mathrm{c}} * *$ & $32,5^{\mathrm{b} *}$ \\
Scalding at $60^{\circ} \mathrm{C}$ & $17,6^{\mathrm{a}}$ & $29,9^{\mathrm{a}}$ & $36,2^{\mathrm{a}}$ \\
Scalding at $80^{\circ} \mathrm{C}$ & $17,7^{\mathrm{a}}$ & $26,8^{\mathrm{b}}$ & $35.0^{\mathrm{ab}}$ \\
Scalding at $100^{\circ} \mathrm{C}$ & $16,8^{\mathrm{a}}$ & $24,7^{\mathrm{bc}}$ & $32,0^{\mathrm{b}}$ \\
Chemical disinfection & $19,9^{\mathrm{b}}$ & $26,4^{\mathrm{b}}$ & $32,9^{\mathrm{b}}$ \\
\hline
\end{tabular}

${ }^{1}$ Mean of 10 replicates

Asterisks indicate significance at $* P<0.0 .05,{ }^{*} P<0.0 .01$; values within the column row followed by the same letter are not significantly different. Mean values in the same column followed by the same letters are not significantly different by Duncan's multiple range test.

Disinfection methods had variable effects on the duration of full colonisation ranging from 16.8 days (scalding in hot water at $100^{\circ} \mathrm{C}$ ) to 19.9 days (chemical disenfection). Obodai, et al. (2003) reported that the spawn run time of P. ostreatus was 15-33 days, while Baysal, Peker, Yalinkilic \& Temiz (2003) confirmed that this varied, in different growing substrates, between 15.8-37.6 days. Spawn run time is influenced by other factors such as the strain, substrate formula, amount of substrate available, spawning rate, spawn distribution and temperature during incubation (Oei, 1991; Philippoussis, Diamantopoulou \& Zervakis, 2003) The faster spawn running in this study may be due to the using wheat bran which is known to stimulate mushroom growth (Shen \& Royse, 2001).

In the study, it was obtained that chemical disinfection required a longer period of time in order that the whole substrate than other methods. Our findings are conformed with Ali, Mehmood, Nawaz, Hanif, \& Wasim (2007) who reported that all the species of Pleurotus treatmented with formalin took more time for the completion of mycelial growth. An aqueous solution of formaldehyde use as a disinfectant as it kills most bacteria and fungi including their spores. Alheeti, Al-Saeedi, Al-Assaffii \& Sabaratnam, (2013), reported that sawdust was treated with antifungal and antibacterial chemicals that may be lead to inhibit fruit bodies formation. Toxic feature of formaldehyde may be slow mycelial growth down .

Scalding in hot water at $60^{\circ} \mathrm{C}$ was the most precocious of all disenfection methods tested, forming their first primordia after 24.1 days of incubation. The pinheads were formed between 7-12 days after the full colonisation of substrate. These results are corroborated by the findings of Ahmad (1986) who reported that $P$. ostreatus completed spawn running in 17-20 days on different substrates and time for pinheads formation was noted as 23-27 days. The fruiting bodies appeared on substrates disinfected by different methods 13-18 days later after spawn running. Our results are in agreement with Tan (1981) who reported that $P$. ostreatus took 2-3 weeks for fruit body formation after spawn running. 


\subsection{Yield and bio-efficiency of oyster mushroom}

There were significant $(\mathrm{P}<0.01)$ effects of the disinfection methods on the total fresh yield and BE (\%) of P. ostreatus HK-35 (Table 2). The harvest of mushrooms has been realized during three flushes and the maximum yield was obtained in first flush than the second and third flush, respectively, except scalding in hot water at $60^{\circ} \mathrm{C}$.

Table 2. Effect of different growing media total fresh yield and BE of Pleurotus ostreatus (HK-35)

\begin{tabular}{|c|c|c|c|c|c|}
\hline \multirow[b]{2}{*}{ Treatment } & \multicolumn{3}{|c|}{ Fresh weight of mushrooms by flushes (g) } & \multirow{2}{*}{$\begin{array}{l}\text { Total fresh } \\
\text { Yield }(\mathrm{g} / \mathrm{kg})^{1}\end{array}$} & \multirow[b]{2}{*}{$\mathrm{BE}(\%)^{1}$} \\
\hline & First & Second & Third & & \\
\hline Autoclave & 130,62 & 81.24 & 28.30 & $240,16 b^{* *}$ & $80,05 \mathrm{~b}^{* *}$ \\
\hline Scalding at $60^{\circ} \mathrm{C}$ & 112.25 & 23.83 & - & $136,08 \mathrm{~d}$ & $46,92 \mathrm{c}$ \\
\hline Scalding at $80^{\circ} \mathrm{C}$ & 142.60 & 64.56 & 56.16 & $263,42 \mathrm{a}$ & 90,83 a \\
\hline Scalding at $100^{\circ} \mathrm{C}$ & 124.31 & 73.25 & 24.70 & $223,26 \mathrm{c}$ & $76,87 \mathrm{~b}$ \\
\hline Chemical disinfection & 133.85 & 82.51 & 54.92 & $271,28 \mathrm{a}$ & 91,96 a \\
\hline
\end{tabular}

${ }^{1}$ Mean of 10 replicates

Asterisks indicate significance at $* P<0.0 .05$, $* * P<0.0 .01$; values within the same column followed by the same letter are not significantly different. Mean values in the same column followed by the same letters are not significantly different by Duncan's multiple range test.

Chemical disinfection was also suggested for disinfection of mushroom growing substrate by a lot of authors (Afyon, 1988; Sanjeev, Rai \& Saxena, 1992; Y1ld1z, 1997). Although, Ali et $a l$., found that cotton waste pasteurized by steam has higher productivity of Pleurotus spp. than cotton waste disinfected chemically by formalin. Chitamba, Shamuyarira, Dube, Mudada, Mapurazi, (2012) reported that cotton waste pasteurized by boiling water had the highest BE, but it was however not significantly different from cotton waste disinfected by Na hypochlorite. Similarly, in our study the best yields $(271.28 \mathrm{~g} / 1 \mathrm{~kg}$ wet growing substrate) were obtained in the case of using chemical sterilization, followed by scalding in hot water at $80^{\circ} \mathrm{C}$. The yield was induced with $12.9 \%$ and $9.6 \%$ in comparison to autoclaved substrate (control), respectively. Oei, (1996), Apahidean, (2006) and Khan, Abbas, Rehman, Haq \& Hanan, (2011) suggested that sterilization of substrates is much more appropriate method for effective cultivation of mushrooms to remove the existance of a number of microorganisms. Khan et al (2011) suggested that lab autoclave (1hr) is a better sterilization method than hot water treatment for 30 minutes. Caral, Vinay, Manasa, Vinothkumar \& Babu (2013), reported that that autoclaving method of physical sterilization yields a better yield in both the substrates (sawdust and straw) than the chemical method of sterilization. But, our findings are confirmed by Quimio, Chang \& Royse (1990) who reported that substrate sterilisation is not ideal since both beneficial and harmful organisms in the substrate are killed. Sanchez (2010) reported also that substrate used for the oyster mushroom cultivation do not require sterilization, but only pasteurisation, which is less expensive to diminish the damages produced by different pathogens (bacteria, moulds or insect pests) on mushroom development and yield. Velázquez-Cedeńo, Mata \& Savoie (2002) cultivated successfully one strain of Pleurotus ostreatus and three strains of $P$. pulmonarius on coffee pulp pasteurized at $80{ }^{\circ} \mathrm{C}$ for $1 \mathrm{~h}$. 


\section{MlMacrothink}

Journal of Agricultural Studies

ISSN 2166-0379

2016, Vol. 4, No. 4

The lowest production, $136.08 \mathrm{~g} / 1 \mathrm{~kg}$, was obtained in substrate disinfected by scalding in hot water at $60^{\circ} \mathrm{C}$, the yield difference given the control being very significant negative. This is half comparative with the disinfected substrate by chemical method. This disinfection method was not suitable in case of yield characteristics of $P$. ostreatus. But, the contamination of the substrate disinfected by scalding in hot water at $60^{\circ} \mathrm{C}$ may have occurred probably due to inadequate time used during disinfection. Hot water pasteurisation of sugarcane baggase was suggesed at $60^{\circ} \mathrm{C}$ for 3 hours by Oseni, Dlamini, Earnshaw \& Masarirambi, (2012)

A much higher yield in the first flush, about $82.5 \%$ from the total yield in substrates disinfected by scalding at $60^{\circ} \mathrm{C}$. Remainder of yield was recorded on the second flush. There is not any yield on thirth flush. Colavolpe Mejía \& Albertó (2014) reported that growth of Trichoderma spp. was practically the same at $60{ }^{\circ} \mathrm{C}$ and $80{ }^{\circ} \mathrm{C}$ and if the mushroom grower uses an immersion in hot water treatment, $60{ }^{\circ} \mathrm{C}$ should be used to save energy and lower production costs. But our results are not confirmed by the findings of Colavolpe et al (2014). The substrates disinfected by scalding at $60^{\circ} \mathrm{C}$ constituted a suitable medium to mycelial growth on the substate, but then growth of Trichoderma spp. was appeared on the sustrate and fruitbodies, it cause decrease of production and a loss in quality of fruitbodies. In other methods, the highest production has been obtained during the first flush about $50 \%$ from the total and second flush between $24.5-30 \%$. Our results are corroborated by the findings of Shah et al. (2004).

The biological efficiency (BE\%) obtained in three harvests with the substrate prepared under the different disenfection conditions is shown in Table 2. These values ranged from $91.96 \%$ and $46.92 \%$. Substrate sterilized by chemicals had the highest BE which was not significantly different from substrate disenfected with immersion in hot water at $80^{\circ} \mathrm{C} \quad(90.83 \%)$. Substrate disenfected with scalding in hot water at $60^{\circ} \mathrm{C}$ for $1 \mathrm{~h}$ had the lowest $\mathrm{BE}$ of 46.92\% compared to others. Mejia \& Alberto (2013) also reported that carbendazim treatment produced highest yields (BE: 106.93\%) while immersion hot water produced the lowest BE with $75.83 \%$. In addition, Diana et al. (2006) determined that the quantities of active chemical substance in the mushroom fruit bodies was much lower than legal limits.

\subsection{Stipe length and pileus diameter growth}

The analysis of variance for avarage weight of fruitbody, pileus diameter and stipe length and width of oyster mushroom indicated significant differences among the various substrate disinfiction methods as shown in Table 3.

Table 3. Effect of different growing media on average mushroom weight, fruitbody diameter, stipe length 
and width of Pleurotus ostreatus $(H K-35)$

\begin{tabular}{|c|c|c|c|c|}
\hline Treatment & $\begin{array}{c}\text { Weight of fruitbody }^{1} \\
\text { (g) }\end{array}$ & $\begin{array}{c}\text { Diameter of pileus }{ }^{1} \\
(\mathrm{~cm})\end{array}$ & $\begin{array}{l}\text { Stipe lenght }{ }^{1} \\
(\mathrm{~cm})\end{array}$ & $\begin{array}{c}\text { Stipe width }^{1} \\
(\mathrm{~cm})\end{array}$ \\
\hline Autoclave & $29.45 b * *$ & $6,08 b^{* *}$ & $3,17 * * \mathrm{c}$ & $1.00 b^{* *}$ \\
\hline Scalding at $60^{\circ} \mathrm{C}$ & $22.15 \mathrm{e}$ & $5.65 \mathrm{c}$ & $3,58 \mathrm{~b}$ & $1.21 \mathrm{a}$ \\
\hline Scalding at $80^{\circ} \mathrm{C}$ & $32.42 \mathrm{a}$ & $7,28 \mathrm{a}$ & $2.81 \mathrm{~d}$ & $1.05 \mathrm{~b}$ \\
\hline Scalding at $100^{\circ} \mathrm{C}$ & $28.22 \mathrm{c}$ & $6,25 \mathrm{~b}$ & $3,24 \mathrm{c}$ & $1.01 \mathrm{~b}$ \\
\hline Chemical disinfection & $25.68 \mathrm{~d}$ & $4,64 \mathrm{~d}$ & $3,92 \mathrm{a}$ & $0.93 b$ \\
\hline
\end{tabular}

${ }^{1}$ Mean of 10 replicates. Asterisks indicate significance at $* P<0.05, * * P<0.01$; values within the same column followed by the same letter are not significantly different. Mean values in the same column followed by the same letters are not significantly different by Duncan's multiple range test

The highest average weight $32.42 \mathrm{~g}$ per fruiting body was recorded from substrate disinfected by scalding in hot water at $80^{\circ} \mathrm{C}$ and minimum on substrate disinfected by scalding in hot water at $60^{\circ} \mathrm{C} 22.15 \mathrm{~g}$ per fruiting body. Kurt (2008) reported that avarage wieght of $P$. ostreatus grown on different substrates between 17.0 -26.27 g. Velázquez-Cedeńo et al. (2002) reported that weights of fruitbodies are different in every flush and fruitbodies in first flushes almost weighed more than the fruitbodies in subsequent flushes. Although average weight per fruiting body was lowest in substrates disifected by formaldehyde, in terms of number of fruiting bodies produced, in same substrate produced significantly higher number of fruiting bodies than all tested methods.

Quality properties of mushroom had been related with the fruit body size such as determination of pileus (cap) and stipe (Owaid, Abed \& Al-Saeedi, 2015). The mean pileus diameter ranged from $4.64 \mathrm{~cm}$ in disenfected by chemicals to $7.28 \mathrm{~cm}$ in scalding in hot water at $80^{\circ} \mathrm{C}$. Pileus diameter of P.ostreatus was determinated in different growing substrates between 4.0-10 cm by Yildiz et al. (2002). The stripe length and width ranges from 2.81-3.92 $\mathrm{cm}$ and $0.93-1.21 \mathrm{~cm}$, respectively. The longest stipe was measured in substrates disinfected by chemicals while the shortest stipes harvested on substates disinfected by scalding in hot water at $80^{\circ} \mathrm{C}$. It was reported that the stipe length varied between $1.21 \mathrm{~cm}$ (Küçükomuzlu, 2003 ) and $3.22 \mathrm{~cm}$ (Güler \& A ğaoğlu, 1995), whereas stipe width was determinated between $0.97 \mathrm{~cm}$ (Güler \& Ağaoğlu, 1995) and $1.12 \mathrm{~cm}$ (Küçükomuzlu, 2003). Our findings are conformed with previous studies. Some undesirable characteristics for marketable quality such as smaller mushroom cap diameter and relatively long mushroom stipe length were determinated when oyster mushroom cultivated on substrate disinfected by formaldehyde as well as high yield and BE (\%). Thus, further research to increase the mushroom quality on substrate disinfected with chemical is necessary. Although we determinated disinfection methods influence fruitbody size, environmental conditions such as temperature, humidity, fresh air and compact material also can affect stalk height, stalk diameter and cap size of mushroom (Onyango, Palapala, Arama, Wagai \& Gichimu 2011). In our study disinfection by scalding in hot water at $80^{\circ} \mathrm{C}$ could shorten mushroom stipe length and enlarge mushroom cap diameter, so it can increase marketable quality of Pleurotus mushroom. 


\section{Conclusions}

The disinfection method affect the mycelium development, yield, BE and size of fruitbodies. The lowest yields were obtained in the scalding in hot water, at $60^{\circ} \mathrm{C}$. Pastuerisation of substrates at lower temperatures (60C) increases the risk of contamination, particularly from Trichoderma species. This method is not sufficient to eliminate all of the microorganisms present in a substrate although they can reduce contaminants to a level that permits mushroom mycelia to colonize all of a substrate competitively then the first flush represents the majority of production but the competitive micro organisms affecting the mushroom yield on the next flushes. Furthermore, higher treatment times such as 2 or more may be investigated in more detail to increase mushroom yield and decrease the infection risk.

In the study, sterilization method exhibited similar yield and quality features with scalding with hot water at $100^{\circ} \mathrm{C}$. The useful micro-organisms are destroyed at these temperatures and due to they cant compete with the harmful microorganisms. This may be responsible for the lower yield.

Scalding with hot water at $80^{\circ} \mathrm{C}$ is easier and cheaper alternative method to autoclave. Although, Jaramillo \& Albertó, (2013) reported that immersion in hot water has some negative aspects such as using a great amount of water and loss of nutrients extracted during heating by lixiviation, in our study, scalding at $80^{\circ} \mathrm{C}$ was also determinated one of the best method for yield and quality of $P$. ostreatus. On the other hand, chemical disenfection method exhibited higher yield and biological efficiency compared to autoclaved substrate. It may suggest a useful technique for substrate disinfection in rural areas because of low cost as well as high yield and $\mathrm{BE}(\%)$. Morever, chemical disinfection can be used for disinfiction of growing substrate safely. In conclusion, chemical treatment of growing substrates for mushroom cultivation can be a good alternative to sterilization to produce a good yield of $P$. ostreatus especially in rural areas, where autoclave sterilisation is not feasible. This method needs further research to increase the mushroom quality. It can be adopted to produce a good quality of fruitbodies by next studies.

\section{References}

Afyon, A. (1988). Pleurotus ostreatus kültüründe farklı sterilizasyon metotlarının verim ve erkenciliğe etkilerinin karşılaştırılması. Doğa Türk Botanik Dergisi, 12(1), 1-7.

Ahmad, S. (1990). Performance of different species of Pleurotus on various agricultural and industrial waste materials. M.Sc. Thesis, Dept. Hort. Univ. Agri., Faisalabad.

Alheeti M.N., Al-Saeedi S.S., Al-Assaffii I.A. \& Sabaratnam V. (2013). Antifungal activities of mycelia and culture filtrate of four oyster mushroom species (Pleurotus spp.) against pathogenic Fungi. The 7th International Medicinal Mushroom Conference, Beijing, China.

Ali, M.A., Mehmood, M.I., Nawaz, R., Hanif, M.A. \& Wasim, R. (2007). Influence of substrate pasteurization methods on the yield of Oyster mushroom (Pleurotus species). Pakistan Journal of Agricultural Sciences, 44(2).

Apahidean, A.I.S. (2006). Ciuperci cultivate flora spontana, Ed.Academic press, 
Cluj-Napoca.

Baysal E., Peker, H., Yalinkilic, M.K. \& Temiz, A. (2003). Cultivation of oyster mushroom on waste paper with some added supplementary materials. Bioresource Technology, 89, 95-97.

Bonatti, M., Karnopp, P., Soares, H.M. \& Furlan, S.A. (2004). Evaluation of Pleurotus ostreatus and Pleurotus sajor- caju nutritional characteristics when cultivated in different lignocellulosic wastes. Food Chemistry, 88(3), 425-428.

Caral D.R., Vinay, P., Manasa, P., Vinothkumar, D. \& Babu, R.N.G. (2013). Comparative study of oyster mushroom (Pleurotus ostreatus) cultivation by physical and chemical method of sterilization using two different substrates. International Journal of Scientific \& Engineering Research, Volume 4, Issue 9, September-2013 898.

Chang, S.T. (2006). Development of the culinary-medicinal mushrooms industry in China: past, present and future. International. Journal of Medicinal Mushroom, 8, 1-17.

Chitamba, J., Shamuyarira, M., Dube, F., Mudada, N. \& Mapurazi, S. (2012). Evaluation of cotton waste, paper waste and jatropha cake for culture of Pleurotus sajor-caju under different pasteurization methods. International Journal of Agronomy and Agricultural Research, Vol. 2, No. 3, p. 1-6.

Cohen, R., Persky, L. \& Hadar, Y. (2002). Biotechnological applications and potential of wood degrading mushrooms of the genus Pleurotus. Applied Microbiology and Biotechnology, 58: 582-594.

Colavolpe, M.B., Mejía, S.J. \& Albertó, E. (2014). Efficiency of treatments for controlling Trichoderma spp during spawning in cultivation of lignicolous mushrooms. Brazilian Journal of Microbiology, 45(4), 1263-1270.

Diana, F., Indea, D., Apahidean, S., Apahidean, M., Rodica, P., Moldovan,Z., Maniutiu,D., Rodica, G. \& Paven, I. (2006). Importance of substrate disinfection on oyster mushroom (Pleurotus Spp.) culture. Notulae Botanicae Horti Agrobotanici , 48-53.

Dias, E.S. (2010). Mushroom cultivation in Brazil: challenges and potential for growth. Ciência e agrotecnologia, 34(4): 795-803.

Eren, E. \& Pekşen, A. (2016). Türkiye'de kültür mantarı sektörünün durumu ve geleceğine bakış. Türk Tarım- Gıda Bilim ve Teknoloji Dergisi, 4(3):189-196.

Ganeshan, G., Tewari, R. \& Bhargova, B. (1989). Influence of residual vegetable crop on yield and mineral content of Pleurotus sajor-caju. Mushroom Science 12(2):91-97.

Gume,B., Diriba Mulata, D. \& Abate, D. (2013). Evaluation of locally available substrates for cultivation of oyster mushroom (Pleurotus ostreatus) in Jimma, Ethiopia. African Journal of Microbiology Research, 7(20): 2228-2237.

Güler, M. \& Ağaoğlu, S. (1995). Kayın Mantarının (Pleurotus spp.) Örtü Altı Yetiștiriciliğ inde Değișik Yetiștirme Ortamlarının Verim ve Kalite Faktörlerine Etkileri. Türkiye II. 
Ulusal Bahçe Bitkileri Kongresi, Çukurova Üniversitesi, 3-6 Ekim, Adana.

Jandaik, C.L. \& Goyal, S.P. (1995). Farm and farming of oyster mushroom (Pleurotus sp.). In: Singh, R.P., Chaube, H.S. (Eds.), 624 K.M. Alananbeh et al. Mushroom Production Technology. G. B. Pant Univ. Agril. and Tech., Pantnagar India, 72-78.

Jaramillo, S. \& Albertó E. (2013). Heat treatment of wheat straw by immersion in hot water decreases mushroom yield in Pleurotus ostreatus. Revista Iberoamericana de Micología, $30(2), 125-129$.

Khan, N.A. (2009). Studies on cultivation of Oyster mushroom on commonly available agricultural wastes in Pleurotus. Ph.D Thesis, Deptt.Pl. Path. Univ. Agri.Faisalabad.

Khan, N.A., Abbas, M., Rehman, A., Haq, I., Hanan, A. (2011). Impact of various sterilization methods using different substrates for yield improvement of Pleurotus spp. Pakistan Journal of Phytopathology, 23(1), 20-23.

Kurt, Ş. (2008). Değişik Tarımsal Atıkların Kayın Mantarı (Pleurotus ostreatus, Pleurotus sajor-caju) Yetiştiriciliğinde Kullanım Olanakları. PhD. Thesis. Çukurova Üniversitesi Fen Bilimleri Enstitüsü.

Küçükomuzlu, B. (2003). Sterilizasyon ve Formaldehit Uygulamaları ile Torba Ağırlıklar1 nın Örtü Altında Yetiștirilen Pleurotus Mantar Türlerinin Gelișme, Verim ve Kalitesi Üzerine Etkileri. M.Sc. Thesis. Ondokuz Mayıs Üniversitesi, Fen Bilimleri Enstitüsü.

Levanon D., Danai O. \& Masaphy S. (1993). Aspects of selecting organic wastes as substrates for edible fungi. In: Zjalic M., editor. Mushroom Production and Research, 23. FAO REUR Techn. Ser., 109-119.

Mejia, J.S. \& Alberto, E. (2013). Heat treatment of wheat straw by immersion in hot water decreases mushroom yield in Pleurotus ostreatus. Revista Iberoamericana de Micología, $30(2), 125-129$.

Marino , R.H., Abreu, L.D., Mesquita, J.B. \& Ribeiro, G.T. (2008). Growth and cultivation of different Pleurotus ostreatus (Jacq.:Fr) kummer strains on cocnut-husk sawdust. Arquivos do Instituto Biológico São Paulo, 75, 1, 29-36.

Masarirambi, M.T., Mamba, M.B. \& Earnshaw, D.M. (2011). Effects of Various Substrates on Growth and Yield of Oyster Mushroom (Pleurotus ostreatus). Asian Journal of Agricultural Sciences, 3(4), 275-280.

Membrillo, I., Sánchez, C., Meneses, M., Favela E. \& Loera, O. (2011). Particle geometry affects differentially substrate composition and enzyme profiles by Pleurotus ostreatus growing on sugar cane bagasse, Bioresource Technology, 102, 1581-1586.

Nwokoye, I., Kuforiji, O. \& Oni, P. (2010). Studies on mycelial growth requirements of Pleurotus ostreatus (fr.) singer. International Journal of Basic and Appled Science, 10, 47-53.

Obodai, M., Cleland-Okine , J., Vowotor , K. A. (2003). Comparative study on the growth and yield of Pleurotus ostreatus mushroom on different lignocellulosic by-products. Journal 
of Industrial Microbiology and Biotechnology, 30, 146-149.

Oei P. (1991). Manual on Mushroom Cultivation: Techniques, Species and Opportunities for Commercial Applications in Developing Countries. Tool Publications, Amsterdam, 1-122.

Oei, P. (1996). Mushroom Cultivation with Special Emphasis on Appropriate Techniques for Developing Countries, 2nd edition, 111-122. Backhuys, Amsterdam, The Netherlands.

Onyango, B.O., Palapala, V.A. Arama, P.F. Wagai, S.O. \& Gichimu, B.M. (2011). Suitability of selected supplemented substrates for cultivation of Kenyan native wood ear mushrooms (Auricularia auricula). American Journal of Food Technology, 6, 395-403.

Oseni, T.O, Dlamini, S.O., Earnshaw, D.M. \& Masarirambi, M.T. (2012). Effect of Substrate Pre-treatment Methods on Oyster Mushroom (Pleurotus ostreatus) Production. International Journal of Agriculture and Biology, 14, 251-255.

Owaid, M.N., Abed, I.A. \& Al-Saeedi, S.S. (2015). Using of date palm fiber mixed with other lignocelluloses toward Pleurotus ostreatus (Higher Basidiomycetes) cultivation. Emirates Journal of Food and Agriculture, 27(7), 556-561.

Philippoussis, A., Diamantopoulou, P. \& Zervakis, G. (2003). Correlation of the properties of several lignocellulosic substrates to the crop performance of the shiitake mushroom Lentinus edodes. World Journal of Microbiology and Biotechnology, 19(6), 551-557.

Pieckenstain, F., Mercuri, O. \& Albertó E. (1999). Mevinolin in naturally occurring specimens of Pleurotus cornucopiae. Micología neotropical aplicada, 12, 1-7.

Royse, D.J. (1985). Effect of spawn run time and substrate nutrition on yield and size of the shiitake mushroom. Mycologia, 77, 756-762.

Royse, J. D. (2013). Trends in Mushrooms Production Worldwide. Proceeding of the VII International Simposium on Mushroom in Brazil and VI National Symposium on Edible Mushrooms: 38-47. Brasilia, DF. Embrapa Recursos Genéticos e Biotecnologia. 412.

Quimio, T.H., Chang, S. T., \& Royse, D. J. (1990). Technical Guidelines for Mushroom Growing in the Tropics, 154. FAO, Plant Production and Protection paper No 106. Rome, Italy.

Sanchez, C. (2010). Cultivation of Pleurotus ostreatus and other edible mushrooms. Applied Microbioogy and. Biotechnology, 85, 1321-1337.

Sanjeev, S., Rai, R.D. \& Saxena, S. (1992). Effect of pretreatments of wheat straw on biodegradation by Pleurotus sajor-caju. Mushroom Research, 1(2), 131-133.

Shah, Z., Ashraf, A.M. \& Ishtiaq, M. (2004). Comparative study on cultivation and yield performance of oyster mushroom (Pleurotus ostreatus) on different substrates (wheat straw, leaves, sawdust). Pakistan Journal of Nutrition, 3(3), $158-160$.

Shen, Q. \& Royse, D. (2001). Effect of nutrient supplement on biological efficiency, quality and crop cycle time on maittake (Griofola frondosa). Applied Microbiology and 
Biotechnology, 57, 74-78.

Silva, E.G., Dias, E.S., Siqueira, F.G. \& Schwan, R.F. (2007). Análise química de corpos de frutificação de Pleurotus sajor-caju cultivado em diferentes concentrações de nitrogênio. Ciência e tecnologia de alimentos, 27(1), 72-75.

Tan, K.K. (1981). Cotton waste is a good substrate for cultivation of (Pleurotus astreatus). The Oyster Mushroom. Mushroom Science, 11(1), 705-710.

Velazquez-Cedeno, M.A., Mata, G. \& Savoie, J.M. (2002). Wastereducing cultivation of Pleurotus ostreatus ve Pleurotus pulmonarius on Coffee Pulp: Changes in the Produstion of Some Lignocelleloytic Enzymes. World Journal of Microbiology \& Biotechnology, 18, 201-207.

Wang, D., Sakoda, A. \& Suzuki, M. (2001). Biological efficiency and nutritional value of Pleurotus ostreatus cultivated on spent beer grain. Bioresource Technology, 78, 293-300.

Y1ldız, A. (1997). Pleurotus florida Fovose'nin gelişim evreleri ve verimi üzerine dezenfektan olarak kullanılan Benlate'nin bazı dozlarının etkileri. Ekoloji Dergisi, 24, 18-20.

Yıldız, S., Y1ldız, Ü.C., Gezer, E.D., \& Temiz, A. (2002). Some lignocellulosic wastes used as raw material in cultivation of the Pleurotus ostreatus culture mushroom. Process Biochemistry, 38, 301- 306.

\section{Copyright Disclaimer}

Copyright for this article is retained by the author(s), with first publication rights granted to the journal.

This is an open-access article distributed under the terms and conditions of the Creative Commons Attribution license (http://creativecommons.org/licenses/by/3.0/). 